\title{
Policy Perspective Analysis of Technology Adoption in Industries
}

\author{
Ayesha Saleem and Kiyohide Higuchi \\ Graduate School of Global Information and Telecommunication Studies, \\ Waseda University, Japan \\ dua@fuji.waseda.jp
}

\begin{abstract}
Technology innovation offers new paradigm for economic development in the globalized world. Business sector role is significant for the development of the country. Technology adoption is very critical and risk taking decisions for the firms. Firms require greater experience and investment for undertaking technology adoption dectsion. This paper demonstrates the trend of technology adoption in firms of developing countries and explores industrial landscape features. The case study of Pakistan is used for analysis, it represents the developing country of Asia. The paper used the contentanalysis method. The key points extracted by using the Socio-economical development indicators. This study is twofold. First highlights the problems and second identify the best strategies for adoption of technology in firms by the government.
\end{abstract}

Keywords: Technology adoption, Eirms, Indtast policy, Government, Economic development

\section{Introduction}

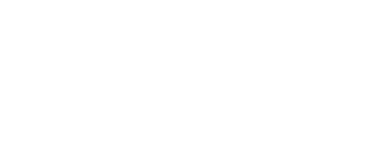

The developing countrie are far behind to catch up the latest technology. The main reason is the technology adoption The countries are using the old technology. The old technology produces less quantity, low quality product, short life span. They import old technology because of less investment in technology and risk aversion. They don't have consultant for selection of appropiate technology. The assessment requires the additional cost. So they are buying old and nnappropriate technology. Developing countries should follow the other developed countries to catch up technology, leapfrog in the short time [1]. We know how to generate electric light, yet many billions do not have access to this amenity. It is also suggested that justas countries such as Malaysia and Korea were able to catch up by adopting technologies from the West, so too many developing countries today can improve their institutions by adopting policies from stronger states. "Foreign direct investment (FDI) has provided southeast Asian countries an alternative route to technology acquisition and opened the way for their participation in global value chains. Large foreign firms and their subsidiaries dominate the economies of Singapore, Malaysia and Thailand, accounting for large parts of high technology exports and constituting the main patents filers" [2].

Developing countries are facing the technology adoption problem. Pakistan is also facing the same problem over last decade. In Pakistan government expenditures and revenues have a stable long run relationship there exists unilateral causality from expenditures to revenues. However, the possibility of budget deficit explosion in the long run is limited. [3] Pakistan ranks in position 130 over 144 countries in the labor market efficiency, position 51 in the capacity of innovation, position 85 in firm-level technology absorption, position 96 in wastefulness of government spending, position 91 in Government procurement of advanced 
technology products and position 108 in ethical behavior of firm. These data indicate the necessity to improve competitiveness in the Pakistan economy, and a way to achieve this goal can be improving firm efficiency via high levels of use of technology by government policies $[4,5]$.Therefore, there is pressing need to take strategic decision for the adoption of technology by government.

It has proved by examine different companies of Pakistan, that inadequate telecommunication infrastructure is the major problem in proper IT implementation. It is recommended that country must upgrade its IT infrastructure and government should concentrate to overcome these problems [6]. The high cost of production due to sudden rise of energy cost is the main concern for the industry. The cost of production increased due to double digit inflation which also devalued Pakistani rupees as compare to US dollar which effects Pakistani textiles product in international market [7]. The lack of Research and development, lack of modernized equipment, tight monetary policies, removal of quota system and high raw material prices are the main reason for the decline of Pakistani textiles industry [8].

The rest of the paper is organized as follows; Section 2 highlights the background of work. Section 3 describes the landscape of Industrial sector. Section 4 shows the trend of technology adoption. Section 5 focuses on the Investment aspect in the Industries. The last section draws a conclusion.

\section{Background}

According to Innovation literature, Innovation is not only based on the R \& D. In most of cases especially in firms it is by the use of innoyative product and process from external source [9]. It also verified that the acquisition of new machinery and equipment is one of the most common innovation activities across firms [10]

The World Bank has been actively analysis the industrial area "normalising" industrial policy and also has done the analysis of the lesson from East Asia and its applicability [11, 12]. Petersen Institute's Noland and Pack analyzed the case of Asia [13, 14] while another institute in Tokyo have launched a programme of basic research for a new industrial policy [15]. Another current survey is "Return of Industrial Policy". [16]

Japan, Korea Netherlands, France, Turkey, Brazil, China, India have Industry policy while USA and UK has some relevant policies about industries. However, some countries Argentina, Colombia, Vietnam and Chile are working on the strategy to improve their econonites [17].

\section{Industry Lândscape}

Pakistan, ffficially the Islamic Republic of Pakistan covers an area of 796,096 square kilometres. Pakistan has a very high growth rate and is the sixth most populous country in the world with an estimated population of 184.3 million in 2012-13. Almost 70\% of the its population (i.e. 110 million) lives in rural areas. Adult literacy rate (10 year and above) is 58 $\%$, literacy is higher in urban areas $(74 \%)$ than in rural areas $(49 \%)$, Public spending on education as percentage of GDP is $2.1 \%$. According to Labour Force Survey of 2010-11, $44.9 \%$ of the total workforce is employed in agriculture sector, $13.02 \%$ in manufacturing, $6.62 \%$ in Construction, $5.23 \%$ in Transport, $13.66 \%$ in services and $0.1 \%$ in others. [18-20] 


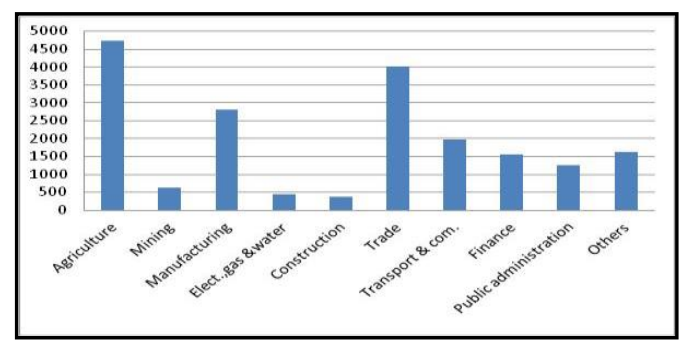

Figure 1. GDP by Industrial Origin at Current Factor Cost Billion Rupees (Source: Asian Development Bank (2013))

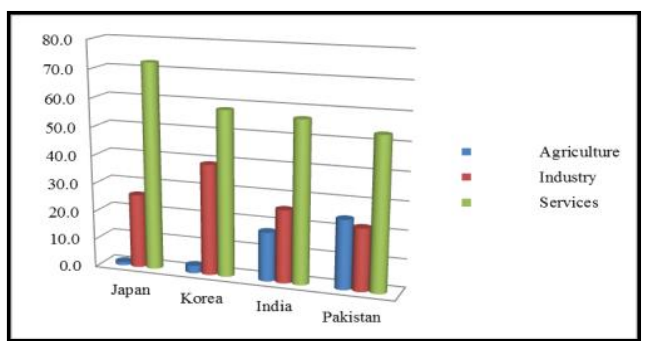

Figure 2. Structure of Output \% of GDP at Current Factor Source: Asian Development Bank (2013)

Agriculture sector is contributing main portion of the GDP, while Industrial Sector is not efficient. However, it is not surprising because it is the same in most of the developing countries. Many developing countries are not able to do R \& D and have high risk and low funds so they rely on the technology from other countries. The decision/to adopt the right technology at right time is also very crucial. However, it s the best solytion considering their current situation.

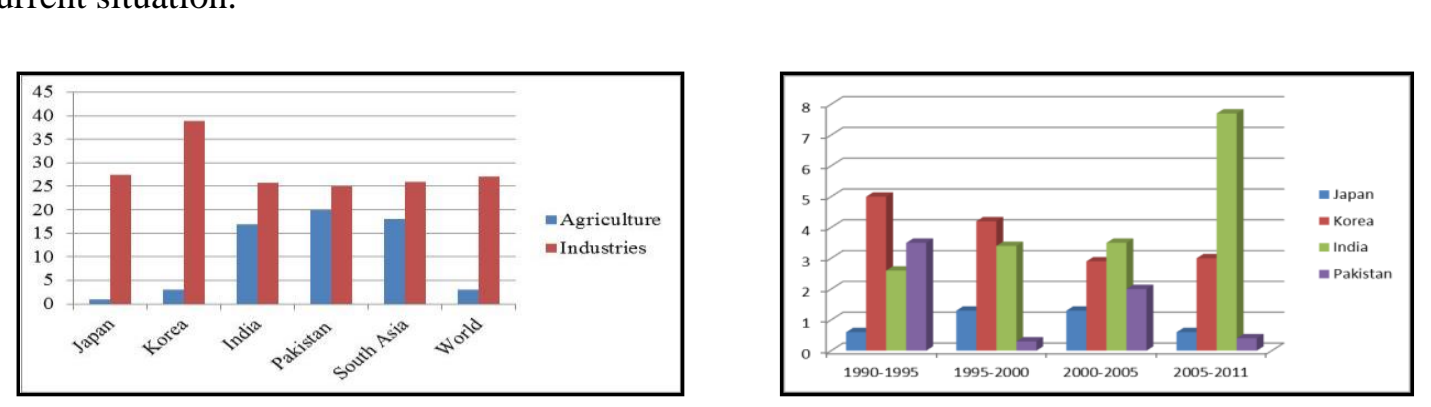

Figure 3. Value added \% of GDP

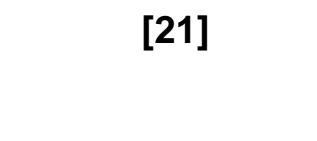

Figure 4. Labour Productivity Growth in Pakistan, 1990-2011 Average Annual Growth Rate of GDP at Constant Basic Prices per Worker, using 2005 PPP [22]

The productivity growth in Pakistan comparative to other countries is higher in hoursworked. The same TPR contribution in GDP growth is (30\%) is significant.

Table 1. Size of the Industry in Different Economy [23]

\begin{tabular}{|l|c|c|c|c|c|c|c|c|c|}
\hline & \multicolumn{3}{|c|}{ Small (5-19) } & \multicolumn{3}{c|}{ Medium (20-99) } & \multicolumn{3}{c|}{ Large (100+) } \\
\hline & $\begin{array}{c}\text { All } \\
\text { Countries }\end{array}$ & $\begin{array}{c}\text { South } \\
\text { Asia }\end{array}$ & Pakistan & $\begin{array}{c}\text { All } \\
\text { Countries }\end{array}$ & $\begin{array}{c}\text { South } \\
\text { Asia }\end{array}$ & Pakistan & $\begin{array}{c}\text { All } \\
\text { Countries }\end{array}$ & $\begin{array}{c}\text { South } \\
\text { Asia }\end{array}$ & Pakistan \\
\hline & 71.3 & 75.9 & 76.2 & 73 & 79.1 & 73.3 & 76 & 82.9 & 74.3 \\
\hline Capacity utilization (\%)* & 5.2 & 2 & -4.4 & 6.1 & 7.8 & -1.6 & 7.2 & 1.3 & -11.0 \\
\hline $\begin{array}{l}\text { Real annual sales growth } \\
(\%)\end{array}$ & 5.6 & 5.3 & 2.0 & 7.6 & 9.5 & 3.9 & 6.9 & 4.4 & 1.8 \\
\hline $\begin{array}{l}\text { Annual employment growth } \\
(\%)\end{array}$ & 0.9 & -1.7 & -6.4 & -0.6 & -0.7 & -4.5 & 1.2 & -2.5 & -12.2 \\
\hline $\begin{array}{l}\text { Annual labor productivity } \\
\text { growth (\%) }\end{array}$ & & & & & & & & & \\
\hline
\end{tabular}

APO Productivity Year Book (2012), grouped the countries on the basis of initial economic level and their speed of catching up. They identified four levels of per capita 
income groups, "Group-L1, with per capita GDP at or above $60 \%$ of the US; Group-L2, from $20 \%$ to under 60\%; Group-L3, from 5\% to under 20\%; and Group-L4, below 5\%". The same, countries are also grouped on the basis of their catch-up speed relative to US, "Group-C1, at $3 \%$ per annum or above; Group-C2, from $1 \%$ to under 3\%; Group-C3, from $0 \%$ to under $1 \%$; and Group-C4, under 0\%". The speed of catch-up is calculated relative to US as the difference in the average annual growth rate of per capita real GDP between each country and the US. Pakistan comes in Group-L4 that is below 5\% of per capita income group and in Group C3 that shows that catch up is very slow in Pakistan and low income group and have failed to catch up. The Pakistan comes with Nepal and Bangladesh. However, other Countries of Group L4 specially, Cambodia and China have progressively catching up. However, Pakistan is the only country with no catch that has moved up one level as it reached to income group boundary from $5.0 \%$ to $5.7 \%$ as of the US. In Pakistan the role of manufacturing sector is becoming important for output growth and employment opportunities.

\section{Technology Adoption Trend}

"Patents filed by foreign applicants can be seen as much as an indicator of international technology diffusion"[22].

Table 2. Intellectual Property Protections Filing of Pakistan auring 2000-2011 by WIPO [24]

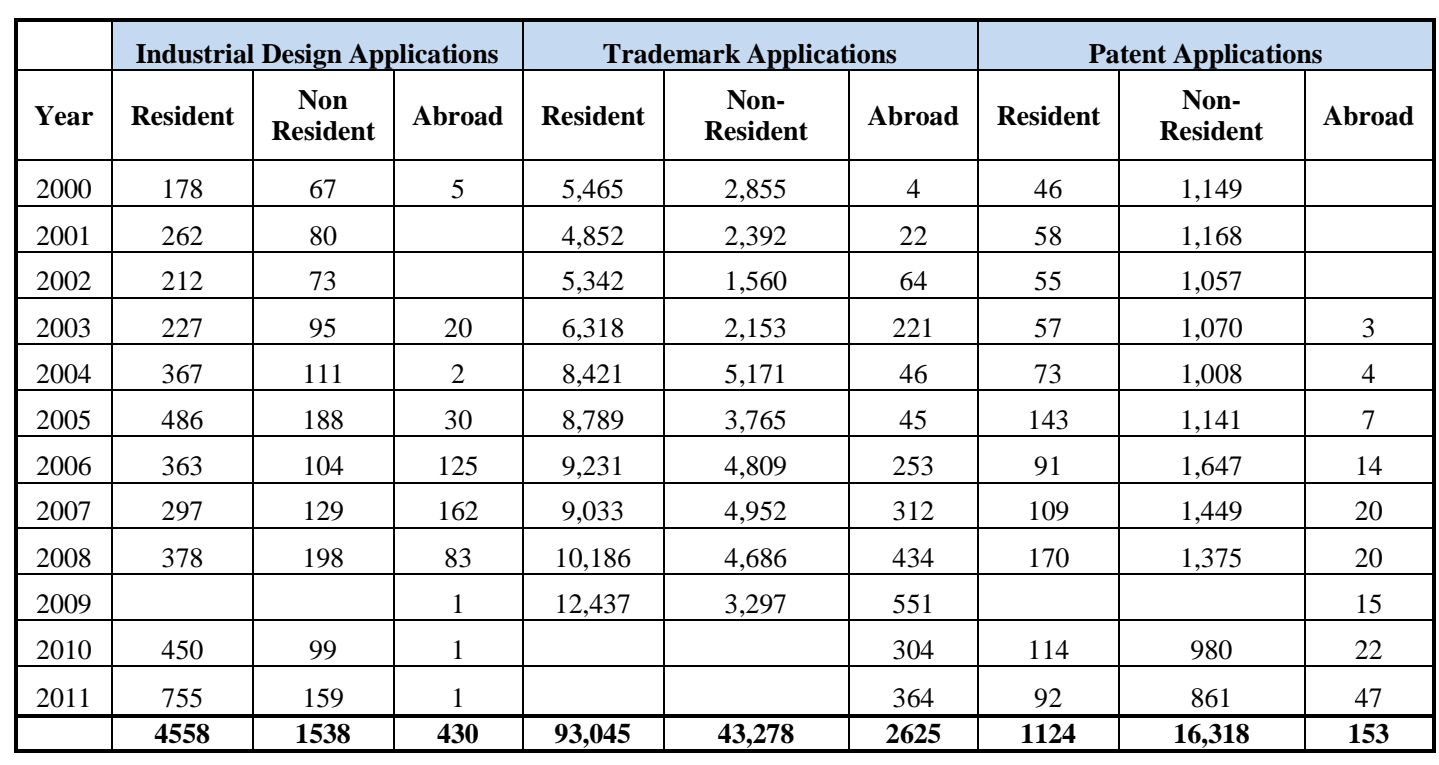

"A patent is an exclusive right granted for an invention, which is a product or a process that provides, in general, a new way of doing something, or offers a new technical solution to a problem. An invention must, in general, fulfill the following conditions to be protected by a patent. It must be of practical use; it must show an element of novelty, that is, some new characteristic which is not known in the body of existing knowledge in its technical field. An industrial design is the ornamental or aesthetic aspect of an article. To be protected under most national laws, an industrial design must be new and/or original. Novelty or originality is determined with respect to the existing design corpus. An industrial design is primarily of an aesthetic nature, and does not protect any technical features of the article to which it is applied". Trademark can be any sign that is suitable for distinguishing goods or services of a particular enterprise from that of other enterprises. Any owner of a registered trademark 
should use the mark. If a trade mark is not used within a period of five years after registration, it can be cancelled, upon request or legal action, on grounds of revocation. Trademarks are of different types. Trademark are registered under these main types i.e. word mark, figurative mark, word and figurative mark, three-dimensional mark, sound mark, tracer mark and others.[24]

Trademarks are the most prominent type of Intellectual Property used in Pakistan. Industrial Design and Trademark Application are comparatively greater in number from the residents while Patent Application are greater in number from the non- residents. The ratio of 10 applications from non-resident to one application from resident, the same pattern is observed in the other developing countries, Singapore, Indonesia and Vietnam. [22] The trend is shown in the Table 2 during the last 10 years. Figure 5 shows that Pharmaceuticals, Computer technology, Audio-visual technology, Engines, pumps, turbines and Organic fine chemistry are the top field of technology for Patent Application. These fields show the better technology diffusion and relatively higher chances for the growth.

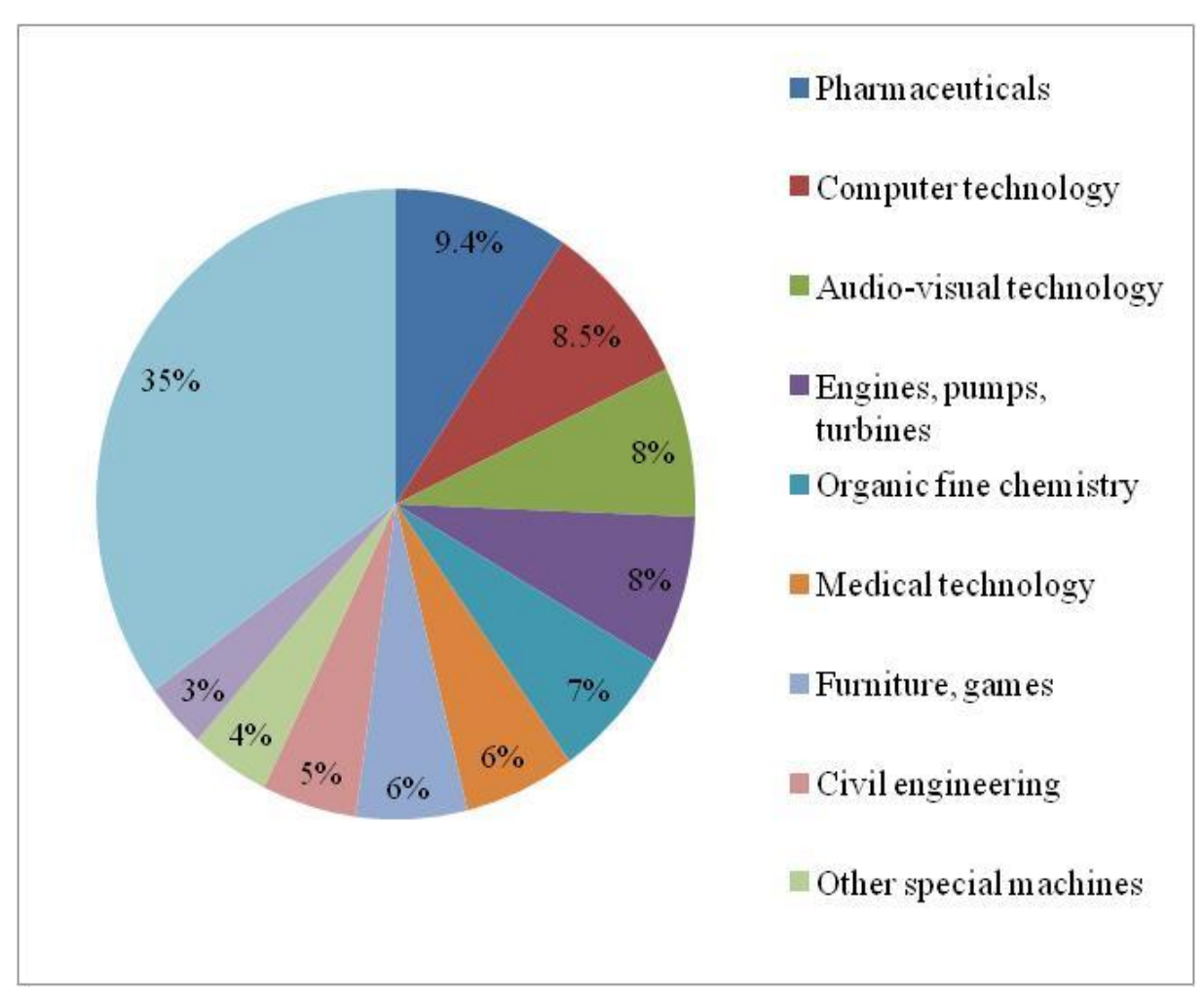

Figure 5. Patent Applications by Top Fields of Technology [24]

Trademark data are increasingly used for economic analysis. Therefore, to analyze the trademark, we used the United State Patent Office data. We analyzed the legal entity type of the trademark of the selected countries Japan, Korea, India and Pakistan. The figure 6 clearly shows the legal entity type percentage of each country. 

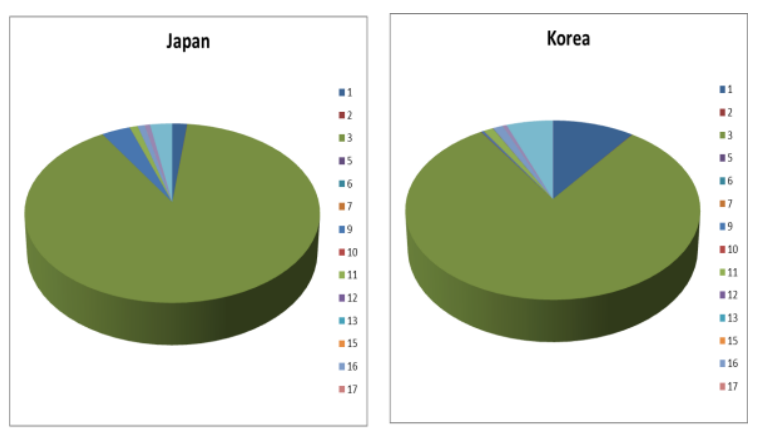

\begin{tabular}{|c|l|}
\hline $\begin{array}{c}\text { Legal } \\
\text { Entity } \\
\text { Type Code }\end{array}$ & Description \\
\hline 3 & Corporation \\
\hline 1 & Individual \\
\hline 99 & Other \\
\hline 2 & Partnership \\
\hline 16 & Limited Liability Company \\
\hline 11 & Company \\
\hline 13 & Limited Partnership \\
\hline 19 & Sole Proprietorship \\
\hline 9 & Joint Stock Company \\
\hline
\end{tabular}
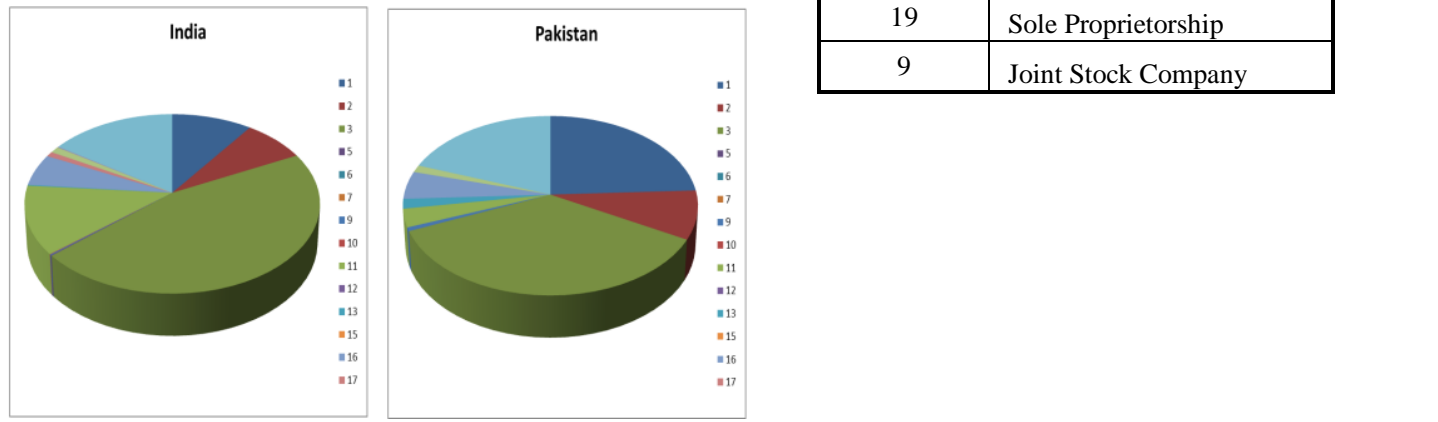

\section{Figure 6. Legal Entity Type of the Countries in USPTO [Source: OECD, Database (2013)]}

\section{Investment in Industrial Sector}

FDI is one of the most important channels thirough which technology is transferred across countries and by encouraging MNEs to estabish local facilities, governments hope to generate the transfer of cechnology to local firms [25]. Pakistan's industrial sector experienced tremendous growth between 2004 and 2006 despite the shortage of electricity. However, it is worth noting that net foreign investment in industries of Pakistan constitutes only $2.5 \%$ of the gountry's GDP. The largest industries of the country are textile, cement, agriculture, fertilizer, steel, tobaceo, edible oil, pharmaceuticals, construction materials, shrimp, sugar food processing, chemicals and machinery.

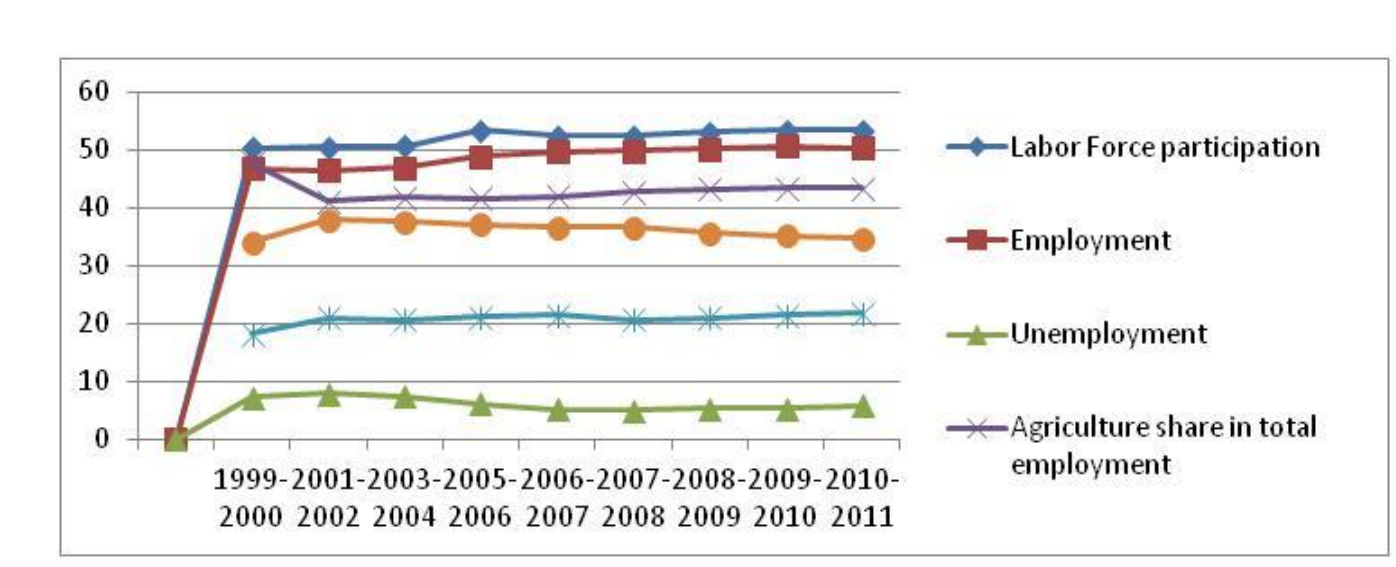

Figure 7. Share of Sector in Total Employment 


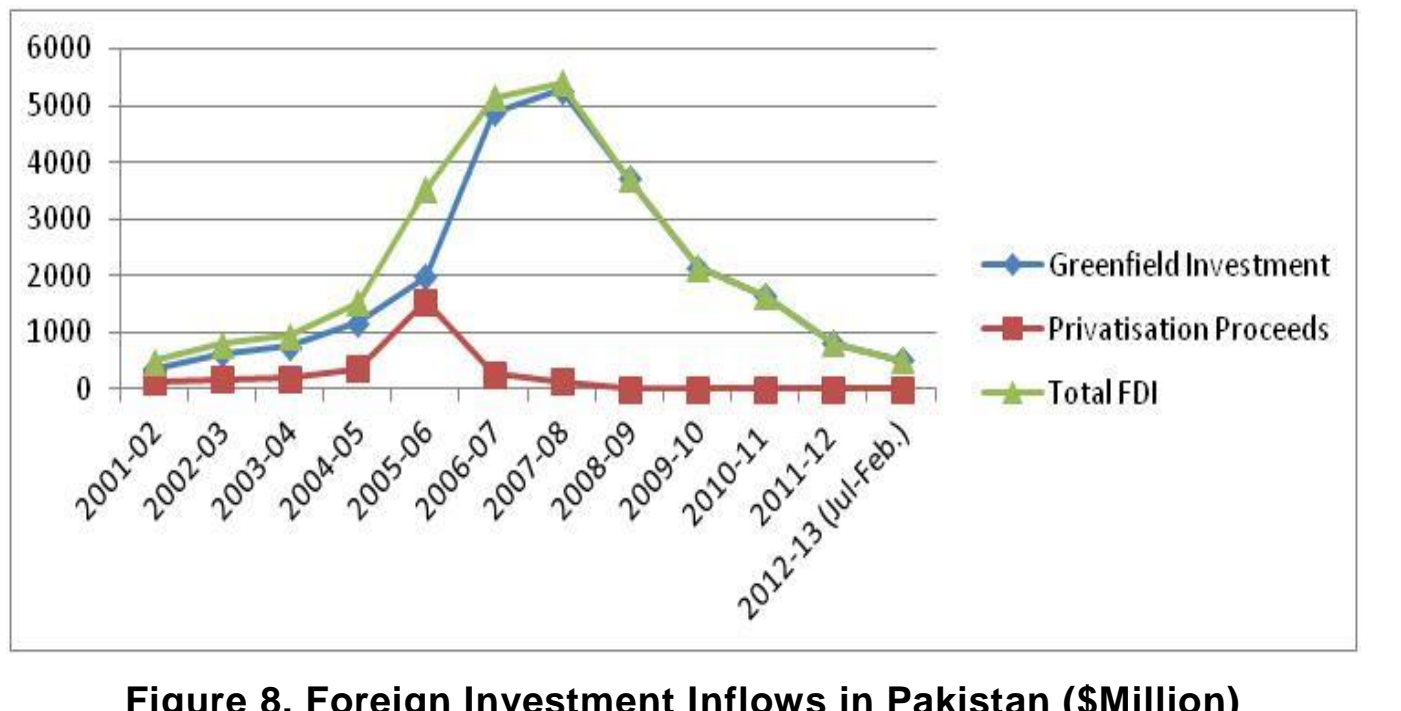

Figure 8. Foreign Investment Inflows in Pakistan (\$Miníon)

The Telecom sector of Pakistan is one of the sectors which have been opened for foreign investment by the Government of Pakistan. Internet and Telephony competition in Pakistan ranks number one according the Economic Forum's Globâl hiormation Technology Report 2012. Pakistan has a unique topography ranging from steep mountains to raging desert. In this hard area $92 \%$ of the land has cellular mobile services. This is one of the key indicators of a successful and advanced cellular market. The telecommunication sector is the main and important contributor in the Nation Exchequer. In 2011 it has made the higher contribution that shows $7 \%$ growth. The telecom reventegeached all time highest that showed the increase of $5.4 \%$ from the previous year $[26]$

Table 3. Economy Source: Enterprise Surveys, World Bank [23]

\begin{tabular}{|l|c|c|c|}
\hline & $\begin{array}{c}\text { All } \\
\text { Countries }\end{array}$ & $\begin{array}{l}\text { South } \\
\text { Asia }\end{array}$ & Pakistan \\
\hline Percent of firms not needing loan & 39.6 & 39.9 & 57.2 \\
\hline Percent of firms using banks to finance investments & 26.2 & 26.9 & 9.7 \\
\hline Proportion of invêstments financed internally (\%) & 69.6 & 73.1 & 88.8 \\
\hline Proportion of investments financed by banks (\%) & 16.5 & 19.0 & 8.4 \\
\hline Proportion ff investments financed by supplier credit (\%) & 4.7 & 0.6 & 0.0 \\
\hline $\begin{array}{l}\text { Proportion of investments financed by equity or stock sales } \\
\text { (\%) }\end{array}$ & 4.6 & 3.4 & 0.7 \\
\hline Percent of firms using banks to finance working capital & 29.5 & 30.4 & 4.6 \\
\hline Proportion of working capital financed by banks (\%) & 11.8 & 14.8 & 1.6 \\
\hline $\begin{array}{l}\text { Proportion of working capital financed by supplier credit } \\
\text { (\%) }\end{array}$ & 12.6 & 5.8 & 11.9 \\
\hline
\end{tabular}


It is clear from the above mentioned table that 57.2 firms don't need loan. Most of the firms are financing internally and equity /stock sale financing is low. Comparing with other countries of the world very few firms use bank investment. These indicator shows that government is not playing role in promoting business in Pakistan. However, for the economic development the role of government to support firms is significant.

\section{Conclusion}

This paper endeavors to clarify the Industrial policy effect for technology adoption in firms. Pakistan ranks in position 130 over 144 countries in the labor market efficiency, position 51 in the capacity of innovation, position 85 in firm-level technology absorption, position 96 in wastefulness of government spending, position 91 in Government procurement of advanced technology products and position 108 in ethical behavior of firm. These data indicate the necessity to improve competitiveness in the Pakistan economy, and a way to achieve this goal can be improving firm efficiency via high levels of use of technology by government policies $[4,5]$. The following points are concluded from the above mentioned content analysis:

1. Government should push the firms to adopt latest technology.

2. Industrial sector of the developing countries are facing financial constraint. The Government should play role to support and enhance the technology adoption capacity.

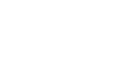

3. Foreign Direct Investment is significant for technology adoption capacity.

This paper has given a broader $10 \mathrm{y}$ of different sector that effect the industrial sector of the country. The papers used the content analysis and the secondary data from different sources.

\section{References}

[1] P. Romer, "Idea gaps and object gaps in economic development", Journal of Monetary Economics, vol. 32, no. 3, (1993), pp. 543-573.

[2] OECD (2013), OECD Reviews of Innovation Policy Innovation in Southeast, OECD Publishing.

[3] Z. Aisha and S. Khatoon "Government Expenditure and Tax Revenue Causality and Cointegration: The Experience of Pakistan 1972-2007”, The Pakistan Development Review, vol. 48, no.4, (2009), pp. 951-959.

[4] World Economic Form, The global competitiveness report 2012-2013, World Economic Forum, (2012).

[5] World Economic Forum, The Global Information Technology Report 2012, World Economic Forum, (2012).

[6] M. Shaukat, M Zafarullah and R. Abdul Wajid, "Information Technology in Pakistan: An Analysis of Problems Faced in IT Implementation by Pakistan's Banking and Manufacturing Companies", Pakistan Journal of Social Sciences (PJSS), vol. 29, no. 1, (2009) June, pp. 13-22.

[7] K. Aftab and K. Mehreen, "Pakistan Textiles Industry Facing new challenges", Research journal of international studies, vol. 14, (2010), pp. 21-29.

[8] F. N. Naqvi, A. Nasir, U. Yousaf, A. Haider and M. Ahmad, "Textile Sector performance", Middle East

Finance \& Economics, no. 13, (2011), pp. 183-189.

[9] A Arundel, C. Bordoy and M. Kanerva, "Neglected Innovators - How Do Innovative Firms That Do Not Perform R\&D Innovate?”, INNO-Metrics Thematic Paper, MERIT, University of Maastricht, (2008).

[10] R. Evangelista and V. Mastrostefano, "Firm Size, Sectors and Countries as Sources of Variety in Innovation", Economics of Innovation and New Technology, vol. 15, no. 3, (2006), pp. 247-270.

[11] D. Rodrik, "Normalizing Industrial Policy", Commission on Growth and Development Working, Washington DC, no. 3, (2008).

[12] S. Yusuf, "East Asian Experience with Industrial Policy and Its Implications for South Africa: Towards An Urban-Industrial Growth Strategy", Washington DC: The World Bank, (2012).

[13] M. Noland and H. Pack, "Industrial Policy in an Era of Globalization: Lessons from Asia", Washington DC: Peterson Institute for International Economics, (2003). 
[14] M. Noland and H. Pack, "The East Asian Industrial Policy Experience: Implications for the Middle East", Peterson Institute for International Economics Working, no. 05-14, (2005).

[15] RIETI, "Basic Research for a New Industrial Policy August 22, 2011 - July 31, 2013", Research Institute of Economy, Trade and Industry, IAA, Tokyo. http://www.rieti.go.jp/en/projects/program/pg-06/index.html\# (Accessed 19 September 2013), (2011).

[16] D. Ciuriak, "The Return of Industrial Policy", Available at SSRN: http://ssrn.com/abstract=1929564 or http://dx.doi.org/10.2139/ssrn.1929564, (2013) May 7.

[17] K. Warwick, "Beyond Industrial Policy: Emerging Issues and New Trends", OECD Science, Technology and Industry Policy Papers, No. 2, OECD Publishing. http://dx.doi.org/10.1787/5k4869clw0xp-en, (2013).

[18] Government of Pakistan. Federal Bureau of Statistics (FBS) Pakistan Statistical Year Book 2011, http://www.pbs.gov.pk/content/pakistan-statistical-year-book-2011.

[19] Economic Survey 2012-13 http://www.finance.gov.pk/survey_1213.html.

[20] A. Saleem and K. Higuchi, "Globalization and ICT Innovation Policy: Absorption Capacity in developing Countries", IEEE the 14th International Conference on Advanced Communication Technology ICACT 2012, February 19-22, 2012, PyeongChang, Korea, (2012).

[21] The World Bank, World Development Indicators, http://data.worldbank.org/indicator, retnived: (2013) September.

[22] APO (2013), APO Productivity Databook 2013, Asian Productivity Organization, Tokyo.

[23] Enterprise Surveys (www.enterprisesurveys.org), World Bank. htth://www.enterprisesurveys.org/Data/ ExploreEconomies/2007/pakistan\#firm-characteristics--size.

[24] WIPO web site, http://www.wipo.int/ipstats/en/statistics/country profile/countries/pk.htnil.

[25] OECD, Attractivess for Innovation: Location Factors for Intemational Investment, OFCD, Paris, (2011).

[26] Pakistan Telecommunication Indicator 2013. Retrieved January 21, 2013, from Pakistan Telcommunication Authority website http://www.pta.gov.pk/.

[27] OECD, OECD Communications Outlook 2013, OECD Publishing. http://dx.doi.org/10.1787/ comms_outlook-2013-en, (2013).

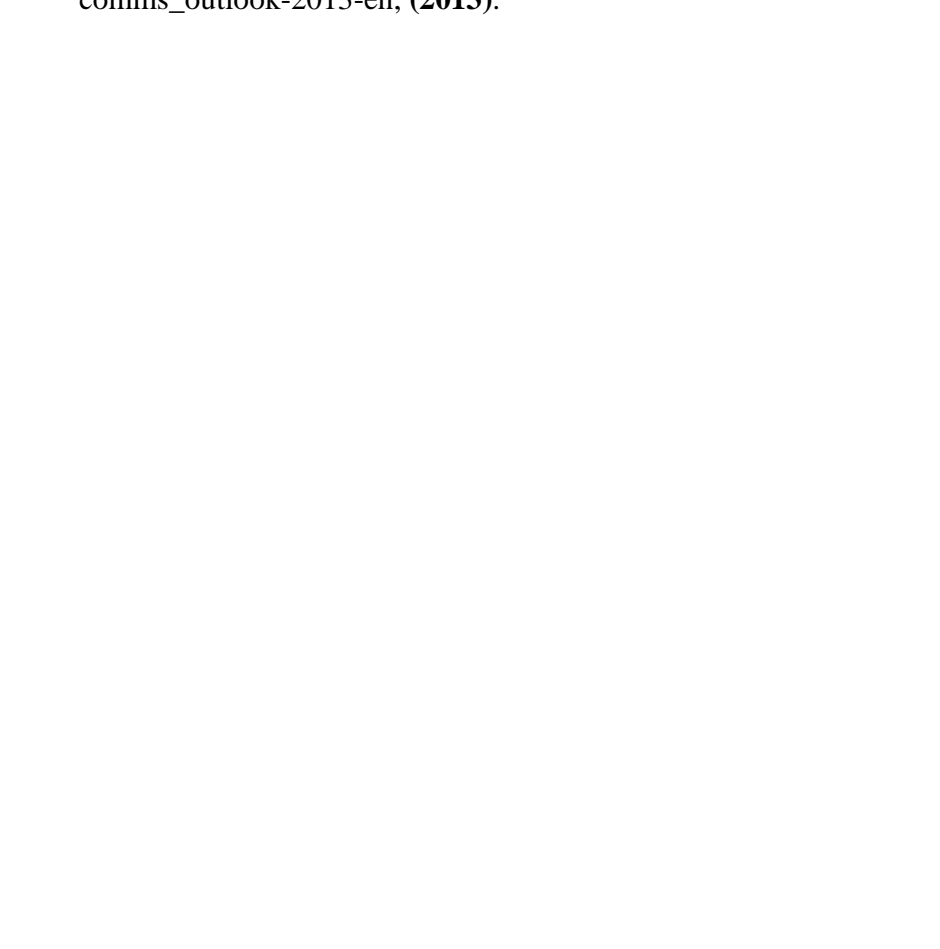


International Journal of Smart Home

Vol.8, No.1 (2014)

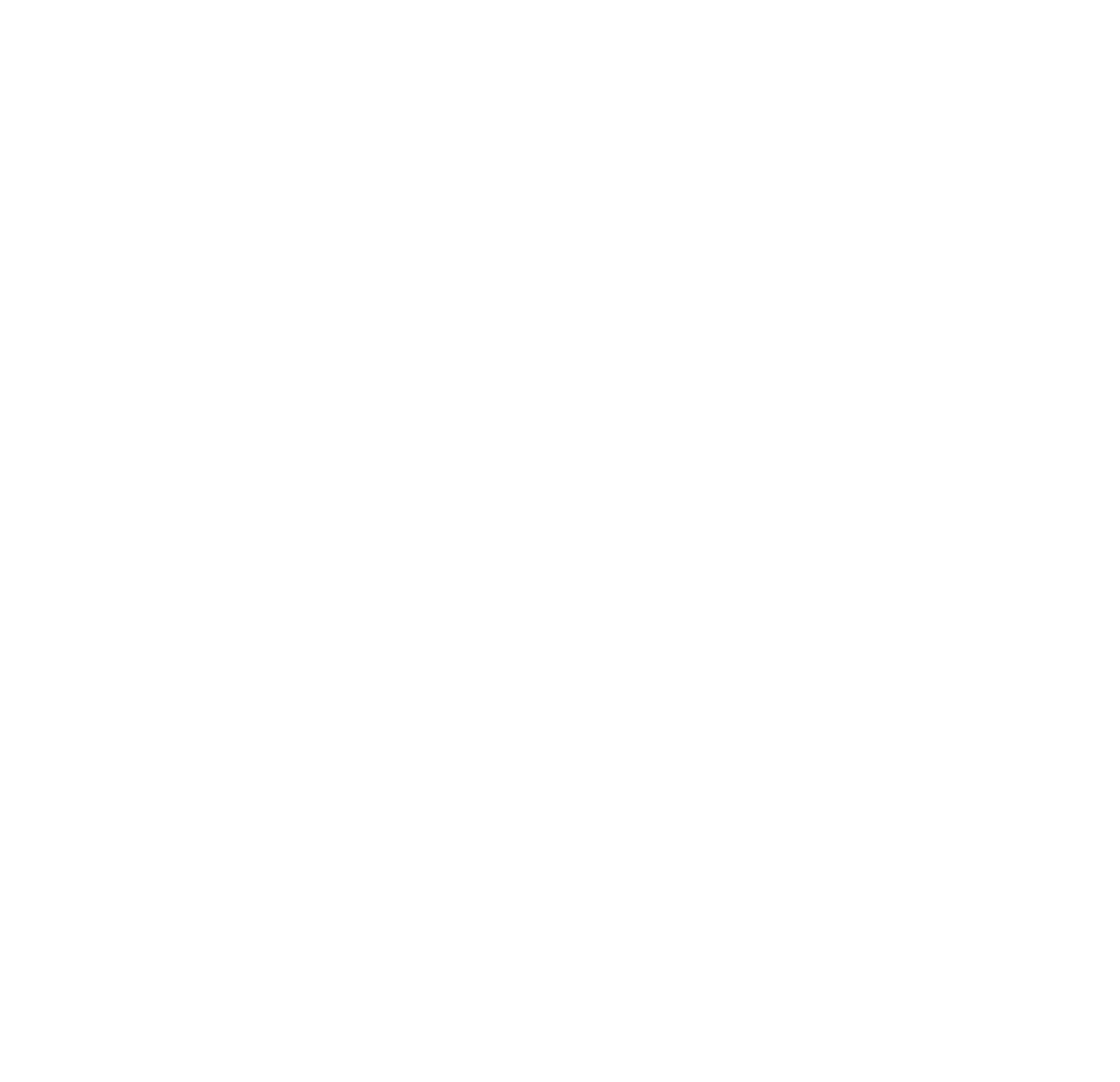

